\title{
Pressure ulcers in palliative \\ home care patients: prevalence and characteristics*
}

\author{
ÚLCERAS POR PRESSÃO EM PACIENTES EM CUIDADOS PALIATIVOS DOMICILIARES: \\ PREVALÊNCIA E CARACTERÍSTICAS
}

\section{ÚLCERAS POR PRESIÓN EN PACIENTES EN CUIDADOS PALIATIVOS DOMICILIARIOS: PREVALENCIA Y CARACTERÍSTICAS}

\section{Ana Carolina de Castro Mendonça Queiroz ${ }^{1}$, Dálete Delalibera Corrêa de Faria Mota ${ }^{2}$, Maria Marcia Bachion ${ }^{3}$, Ana Cássia Mendes Ferreira ${ }^{4}$}

\begin{abstract}
Persons in palliative care develop pressure ulcers (PU) as death approaches, but the extent of the problem is still unkno$w n$. The objectives were to identify the prevalence of pressure ulcers in people with cancer in palliative home care, compare the socio-demographic and clinical profile of patients with and without pressure ulcers, and analyze the characteristics of the ulcers. This descriptive, cross-sectional study included 64 people with advanced cancer in palliative home care. Twelve of them (18.8\%) had PU, of whom $75.0 \%$ were men. The participants had one to three PU, amounting to 19 lesions, $89.4 \%$ of those developed at home and $47.4 \%$ at stage 3 . The presence of PU was higher among those who had a history of previous wound. PU consisted of a significant event occurring in the studied population, indicating that preventive measures should be included in the home palliative care health team.
\end{abstract}

\section{RESUMO}

Pessoas em cuidados paliativos desenvolvem úlceras por pressão (UPP) à medida que a morte se aproxima, contudo, pouco se sabe sobre a dimensão do problema. Realizou-se um estudo descritivo, transversal e quantitativo, cujos objetivos foram: identificar a prevalência de úlceras por pressão em pessoas com câncer em cuidados paliativos domiciliares, comparar o perfil sociodemográfico e clínico dos pacientes com e sem úlceras por pressão e analisar as características das úlceras encontradas nessas pessoas. A amostra foi constituída por 64 pessoas com câncer avançado, em cuidados paliativos domiciliares, a maioria $(75,0 \%)$ do sexo masculino. Doze $(18,8 \%)$ apresentaram de uma a três UPP, totalizando 19 lesões, 89,4\% desenvolvidas no domicílio e $47,4 \%$ de estágio 3 . A presença de UPP foi maior entre aqueles que tinham história de lesão anterior. A UPP é um evento de ocorrência expressiva na população estudada, indicando que medidas preventivas devem ser incluídas na atuação das equipes de cuidados paliativos domiciliares.

\section{RESUMEN}

Las personas en cuidados paliativos desarrollan úlceras por presión (UPP) a medida que se acerca la muerte, sin embargo, se desconoce la magnitud del problema. Se realizó un estudio descriptivo, transversal y cuantitativo cuyos objetivos fueron: identificar la prevalencia de las úlceras por presión en pacientes con cáncer en cuidados paliativos domiciliarios, comparar el perfil sociodemográfico y clínico de los pacientes con y sin úlceras por presión y analizar las características de las úlceras encontradas en estas personas. La muestra se constituyó de 64 personas con cáncer avanzado, la mayoría de sexo masculino $(75,0 \%)$ en cuidados paliativos domiciliarios. Doce participantes $(18,8 \%)$ tuvieron entre una a tres UPP, con un total de 19 lesiones, de las cuales el $89,4 \%$ se desarrolló en el domicilio y el $47,4 \%$ estaban en la etapa 3 . La prevalencia de UPP fue mayor entre los que tenían antecedentes de lesiones previas. El desarrollo de UPP es un hecho relevante que ocurre en la población estudiada, lo que indica que es primordial incluir medidas preventivas en el trabajo de los equipos de cuidados paliativos domiciliarios.

\author{
DESCRIPTORES \\ Neoplasias \\ Úlcera por presión \\ Cuidados paliativos \\ Enfermería oncológica \\ Atención domiciliaria de salud.
}

* Extracted from the dissertation "Pressure ulcers in people with cancer in palliative home care", Nursing Post graduation Program, Universidade Federal de Goiás, 2013. ${ }^{1}$ MSc Nursing Student, Universidade Federal de Goiás, Goiânia, GO, Brazil. carolinacmq@gmail.com ${ }^{2}$ Adjunct Professor, School of Nursing, Universidade Federal de Goiás, Goiânia, GO, Brazil. ${ }^{3}$ Titular Professor, School of Nursing, Universidade Federal de Goiás, Goiânia, GO, Brazil. ${ }^{4}$ Professor, Universidade Alfredo Nasser, Goiânia, GO, Brazil. 


\section{INTRODUCTION}

Multiple chronic diseases evolve to conditions in which there is no possibility of cure and the prognosis is the end of life in around a year ${ }^{(1)}$. In this condition, palliative care (PC) is indicated. It is defined as the approach that promotes quality of life through the prevention and relief of suffering for patients and their families in face of diseases that threaten the continuity of life. PC requires early identification, evaluation and impeccable treatment of pain and other problems of physical, psychosocial and spiritual nature ${ }^{(1-2)}$. PC is also guided by the concept of death as a natural process of life that permeates the everyday practice of nursing, whose professionals are the most present in terminally ill individuals ${ }^{(3)}$.

Among the many groups that receive PC are people with cancer out of therapeutic possibilities of cure ${ }^{(1)}$. Although much progress has been made in the treatment and cure of neoplastic diseases, mortality remains high, representing the second leading cause of all deaths in Brazil(4).

Patients with advanced disease, including those in palliative care, often have pressure ulcers (PU), wounds resulting from skin lesion or adjacent tissue caused by pressure, shear and/or friction, which can and should be avoided. Therefore, the healthcare team should incorporate the knowledge about prevention and treatment, ensure reduction in the incidence and, whenever possible, heal and minimize complications ${ }^{(4-5)}$.

PU are an important problem for the healthcare industry due to its high incidence, prevalence, increased morbidity and mortality, as well as the increase in costs with prophylactic and therapeutic measures ${ }^{(5)}$.

Prevalence of PU has been identified in $10.5-26.0 \%$ of patients in palliative process in various care settings ${ }^{(6-7)}$. Most lesions arise in the last days of life(8). As death approaches and $\mathrm{PU}$ appear, emerges the questioning regarding the extent of the problem and the actions that nursing could develop with the patients in order to promote comfort and maintain the integrity, without investing on futile treatments.

The nursing must be able to identify the care needs of their clientele. Thus, it is necessary to know in depth the issue of PU in people with oncological changes in palliative care, including the frequency of its occurrence, lesion characteristics and associated factors.

The present study aims to identify the prevalence of PU in people with cancer in palliative care at home, comparing the sociodemographic and clinical profile of patients with and without $\mathrm{PU}$, and analyzing the characteristics of the PU found.

\section{METHOD}

This is a descriptive, cross-sectional study of quantitative approach carried out in the households of people assisted by the Group of Palliative Support to the Oncology Patient (GAPPO - Grupo de Apoio Paliativo ao Paciente Oncológico) of the ACCG. This group has been organized since 1996 with the aim of providing home palliative care by a multidisciplinary team.

The study population consisted of 90 adults with advanced cancer, out of therapeutic possibilities of healing, living in the city and the metropolitan area of Goiânia, attended by Gappo. Throughout the recruitment process, there were 26 losses because eight patients returned to their hometowns and 18 died before the beginning of data collection. None of the participants refused to participate in the study.

The dependent variable was the pressure ulcer, assessed by the Pressure Ulcer Healing Scale (PUSH), an instrument that considers the area, the amount of exudate and the appearance of the wound bed. The sub-scores assigned to those items generate a total score, ranging from 0 to 17 . $\mathrm{Hi}-$ gher scores indicate worse conditions of the $\mathrm{PU}(9-10)$.

The remaining variables refer to sociodemographic and clinical data: age, gender, race, marital status, education, religion, history of smoking or alcohol consumption, cardiovascular problems, underweight $(\mathrm{IMC}<18.5 \mathrm{Kg} / \mathrm{m} 2)$, urinary incontinence, functionality, reports of previous PU wounds and receiving guidance for its prevention.

Functionality was assessed by three instruments: the functional capacity was assessed by the Karnofsky Performance Status Scale (KPS) which classifies functional impairment resulting from the disease and treatments $^{(4)}$; the basic activities of daily living (ADL) were assessed by the Katz Index ${ }^{(11)}$ and the instrumental activities of daily living (IADL) were assessed by the Lawton Scale ${ }^{(11)}$. The three aforementioned instruments have been validated for use in $\mathrm{Brazi}^{(4,11)}$.

Data collection was carried out between December 2011 and July 2012. The GAPPO institution was visited to collect information about the people attended by their service. These people were contacted by telephone and the ones who agreed to participate in the study received visits at home. After acceptance to participate in the study and signing the informed consent form, started the data collection through interviews and clinical evaluation. In cases of presence of PU, the wounds were assessed.

The Statistical Package of Social Sciences for Windows (SPSS) version 17.2 was used for data analysis, which were expressed as absolute and percentage frequency, measures of central tendency and dispersion. For identification of prevalence, it was calculated the ratio between the number of PU cases and the total number of patients included in the study. The Fisher's exact test was used to compare the profiles of the

$\begin{aligned} \text { Rev Esc Enferm USP } & \text { Pressure ulcers in palliative home care patients: } \\ 2014 ; 48(2): 000-000 & \text { prevalence and characteristics } \\ \text { www.ee.usp.br/reeusp/ } & \text { Queiroz ACCM, Mota DDCF, Bachion MM } \\ \text { Ferreira ACM } & \end{aligned}$


groups of patients with and without PU and associations with $p<0.05$ were considered significant.

The study was approved by the Committee of Ethics in Research of the Association of Cancer Combat of Goiás (ACCG) and by the Hospital das Clínicas of the Universidade Federal de Goiás, under protocol numbers 006/2011 and 019/2011, respectively.

\section{RESULTS}

Among the 64 participants, the prevalence of PU was $18.8 \%$, and lesions were found in 12 people during the assessments at their homes. The sociodemographic characterization of participants is shown in table 1 . No statistically significant differences were found in the comparison of data between those who had pressure ulcers and those who did not have.

Table 1 - Sociodemographic characteristics of patients attended by a home palliative care service - Goiânia, GO, Brazil, Dec/2011 to $\mathrm{Jul} / 2012$

\begin{tabular}{|c|c|c|c|c|c|c|}
\hline \multirow{2}{*}{ Variables } & \multicolumn{6}{|c|}{ PU } \\
\hline & Yes & $\%$ & No & $\%$ & OR & p value \\
\hline \multicolumn{7}{|l|}{ Gender } \\
\hline Male & 9 & 75.0 & 35 & 67.3 & 1.46 & 0.739 \\
\hline Female & 3 & 25.0 & 17 & 32.7 & & \\
\hline \multicolumn{7}{|l|}{ Age } \\
\hline Greater than 70 years & 4 & 33.3 & 25 & 48.1 & 0.54 & 0.552 \\
\hline Less than 70 years & 8 & 66.7 & 27 & 51.9 & & \\
\hline \multicolumn{7}{|l|}{ Race } \\
\hline Black and brown & 5 & 41.7 & 30 & 57.7 & 0.52 & 0.352 \\
\hline White & 7 & 58.3 & 22 & 42.3 & & \\
\hline \multicolumn{7}{|l|}{ Education } \\
\hline Illiterate until incomplete primary school & 8 & 66.7 & 36 & 69.2 & 0.89 & 1.000 \\
\hline Primary school until university graduation & 4 & 33.3 & 16 & 30.8 & & \\
\hline \multicolumn{7}{|l|}{ Living with partner } \\
\hline No & 8 & 66.7 & 38 & 73.1 & 0.74 & 0.451 \\
\hline Yes & 4 & 33.3 & 14 & 26.9 & & \\
\hline \multicolumn{7}{|l|}{ Religion } \\
\hline Protestant & 8 & 66,7 & 23 & 44.2 & - & 0.263 \\
\hline Catholic & 4 & 33.3 & 23 & 44.2 & & \\
\hline Others & 0 & 0.0 & 6 & 11.5 & & \\
\hline
\end{tabular}

Note: $(\mathrm{N}=64)$

The clinical characteristics of participants are shown in table 2. There was a significant difference between the groups only regarding the variable 'previously presented PU'.

Among the 12 patients with PU, 58.3\% developed just one lesion, $25 \%$ developed two lesions and $16.7 \%$ three lesions, a total of 19 ulcers. Regarding the environment in which occurred the onset of lesions, $89.4 \%$ happened at home and $10.6 \%$ in the hospital setting. In relation to the GAPPO home palliative care service, $41.6 \%$ of patients developed PU during the assistance of the studied service and $58.3 \%$ already had PU when admitted in the service.

The characteristics of $\mathrm{PU}$ are shown in table 3.

Table 2 - Clinical characteristics of people with cancer treated by a home palliative care service - Goiânia, GO, Brazil, Dec/2011 to $\mathrm{Jul} / 2012$

\begin{tabular}{|c|c|c|c|c|c|c|}
\hline \multirow{2}{*}{ Variables } & \multicolumn{6}{|c|}{ PU } \\
\hline & Yes & $\%$ & No & $\%$ & OR & p value \\
\hline \multicolumn{7}{|l|}{ Smoker and former smoker } \\
\hline Yes & 7 & 58.3 & 38 & 73.1 & 0.52 & 0.318 \\
\hline No & 5 & 41.7 & 14 & 26.9 & & \\
\hline
\end{tabular}


Continuation...

\begin{tabular}{|c|c|c|c|c|c|c|}
\hline \multirow{2}{*}{ Variables } & \multicolumn{6}{|c|}{ PU } \\
\hline & Yes & $\%$ & No & $\%$ & OR & $p$ value \\
\hline \multicolumn{7}{|l|}{ Alcoholic and ex-alcoholic } \\
\hline Yes & 4 & 33.3 & 32 & 61.5 & 0.31 & 0.108 \\
\hline No & 8 & 66.7 & 20 & 38.5 & & \\
\hline \multicolumn{7}{|l|}{ Karnofsky } \\
\hline Impaired performace & 8 & 66.7 & 44 & 84.6 & 0.36 & 0.215 \\
\hline Good performance & 4 & 33.3 & 8 & 15.4 & & \\
\hline \multicolumn{7}{|l|}{ Dependence for ADL } \\
\hline Yes & 12 & 100.0 & 37 & 71.2 & - & 0.054 \\
\hline No & 0 & 0.0 & 15 & 28.8 & & \\
\hline \multicolumn{7}{|l|}{ Dependence for IADL } \\
\hline Yes & 11 & 91.7 & 49,0 & 94.2 & 0.67 & 0.74 \\
\hline No & 1 & 8.3 & 3 & 5.8 & & \\
\hline \multicolumn{7}{|l|}{ Urinary continence } \\
\hline No & 5 & 41.7 & 32 & 61.5 & 0.45 & 0.331 \\
\hline Yes & 7 & 58.3 & 20 & 38.5 & & \\
\hline \multicolumn{7}{|l|}{ Cardiovascular problems } \\
\hline Yes & 6 & 50.0 & 24 & 46.2 & 1.17 & 1.000 \\
\hline No & 6 & 50.0 & 28 & 53.8 & & \\
\hline \multicolumn{7}{|l|}{ Underweight $($ IMC $<18.5)$} \\
\hline Yes & 6 & 50.0 & 11 & 21,2 & 3.73 & 0.062 \\
\hline No & 6 & 50.0 & 41 & 78.8 & & \\
\hline \multicolumn{7}{|l|}{ PU previously presented } \\
\hline Yes & 5 & 41.7 & 5 & 9.6 & 6.71 & 0.015 \\
\hline No & 7 & 58.3 & 47 & 90.4 & & \\
\hline \multicolumn{7}{|c|}{ Received guidance for the prevention of $\mathrm{PU}$} \\
\hline No & 10 & 83.3 & 43 & 82.7 & 1.05 & 1.000 \\
\hline Yes & 2 & 16.7 & 9 & 17.3 & & \\
\hline
\end{tabular}

Note: $(\mathrm{N}=64)$

Table 3 - Characterization of the 19 pressure ulcers of 12 patients treated by a home palliative care service - Goiânia, GO, Brazil, Dec/2011 to Jul/2012

\begin{tabular}{lccc}
\hline PU characteristics & Values & Frequency & \% \\
\hline \multirow{2}{*}{ Topography } & Sacral & 14 & 73.7 \\
& Trochanteric & 3 & 15.8 \\
& Ear & 2 & 10.5 \\
& 1 & 2 & 10.5 \\
Stage classification & 2 & 3 & 15.8 \\
& 3 & 9 & 47.4 \\
& 4 & 4 & 5.3 \\
PUSH score & Unstageable & 0 & 21.0 \\
& Suspected deep tissue injury & Mean (SD); Median; Min- Max & 0.0 \\
\end{tabular}

\section{DISCUSSION}

\section{Prevalence of $P U$ in people with cancer in palliative home care}

The prevalence of $18.8 \%$ of PU is an intermediate value, if compared to results of other studies related to patients in palliative care ${ }^{(6-8,12-16)}$. In studies carried out in other countries, the prevalence of $\mathrm{PU}$ in people in palliative care (PC) ranged from 10.5 to $26 \%{ }^{(6-8,12)}$. In Canada, a study with people with advanced cancer from a home care agency identified a prevalence of PU of $10.5 \%^{(7)}$. The prevalence of PU was $12 \%$ in a PC unit in the United Kingdom ${ }^{(6)}, 22 \%$ in a hospice in Italy ${ }^{(8)}$ and $26 \%$ in another located in the USA ${ }^{(12)}$. 
This prevalence also represents an intermediate finding in relation to other people who were not in PC, in which the identified values ranged from 13.5 to $35.2 \%^{(13-15)}$. A study in a long-stay institution for the elderly in Portugal found a prevalence of PU of $23 \%^{(14)}$. A study carried out in the U.S. on the relationship between race and PU identified overall prevalence of $14.5 \%{ }^{(13)}$. The prevalence of PU in patients from an Intensive Care Unit in Brazil was $35,2 \%{ }^{(15)}$.

The context of the onset of $\mathrm{PU}$ is related to intrinsic and extrinsic conditions of the person with the lesion ${ }^{(5)}$. Patients in palliation with different underlying diseases may have metabolic and oxygenation conditions more or less severe ${ }^{(4)}$, which can partly explain the differences in prevalence of PU by comparing the findings of the present study and of other studies.

\section{Characterization of people with cancer in home palliative care}

Most participants in this study were males. Although no difference was found in relation to gender between the groups with and without PU, a study with patients in PC found a significant association between $\mathrm{PU}$ and the male gender $^{(8)}$. The difference of care needed for each gender - more difficult maneuvers and placements in men, for example - can be a cause for this difference, besides the reduced willingness of men to admit the need for additional formal care ${ }^{(8)}$.

As for skin color, almost half of the participants were black or brown. The studies on people in PC do not contain data relating to skin color. In other population groups, the results are divergent and studies sometimes indicate a higher prevalence among black and brown people and sometimes among white people $e^{(13,15-16)}$.

Regarding age, a third of participants with PU were older than 70 years. A study with patients in PCidentified that the average age of those with PU was 77.7 years, although no significant association was found between PU and age ${ }^{(17)}$.

Seniors are at greater risk of developing impaired skin integrity, including PU because with advancing age there is a decrease in turgor and elasticity of the skin and changes of immunological mechanisms and tactile sensitivity, which could function as intrinsic barriers of protection ${ }^{(18)}$. Nevertheless, no association between age and PU has been found, even in the institutionalized elderly ${ }^{(19)}$. This can happen because the PU are multifactorial and risk may be greater in younger people that have worse conditions of mobility, nutrition or oxygenation.

With regard to alcohol and tobacco, approximately $60 \%$ of individuals with PU were smokers and one-third were alcoholics. It is known that smoking causes the loss of functional hemoglobin, lung problems and poor oxygenation of the tissues, and that nicotine produces vasoconstriction $^{(20)}$, which could increase the risk of PU. However, the studies do not have data for this variable ${ }^{(20-21)}$.
In an experimental study with induced PU in rats, it was found that nicotine increases the risk of PU induced by skin inflammatory mediators ${ }^{(20)}$. Among patients with spinal cord injury with PU, $41 \%$ were smokers, but this variable was not significantly associated with the presence of the lesion $^{(21)}$. There is no data in the literature relating PU to alcoholism. Although it causes serious changes in health, it is not known if alcohol affects the risk of developing PU.

Most participants of the present study had a score of KPS $<50 \%$, which was expected due to the fact that they have cancer and were in PC(4). Low scores on the KPS showed no differential distribution in people with and without PU. However, a previous study found association of low KPS scores with the development of PU in patients with cancer and in $\mathrm{PC}^{(12)}$. A study carried out at a hospice found that all patients with PU had impaired functional capacity and among these, $76 \%$ had a score of KPS $<30 \%{ }^{(8)}$.

All the participants of this study were dependent for ADL and over $90 \%$ for IADL. Studies analyzing the ADL and $\mathrm{PU}$ are scarce, and the data of this study are consistent with the trend in the literature that investigated the issue ${ }^{(22-23)}$. A study with institutionalized elderly found that for each increase of one point on the scale of ADL, the risk of PU increases 1.38 times $^{(14)}$. No studies were found regarding the IADL and $\mathrm{PU}$, but it is understood that the better the functionality for such activities, the lower the risk for PU.

The literature indicates that maceration and loss of natural oils from the skin due to frequent cleaning in people with incontinence leave the skin more fragile, increasing the risk of $P U^{(24)}$. However in this study no association was found between PU and this variable.

Urinary incontinence was present in $51.9 \%$ of inpatients with PU in a hospital of Fortaleza ${ }^{(25)}$, but the relation between these events was not studied. Urinary incontinence was also found in $56 \%$ of the population served in primary health care in Spain ${ }^{(26)}$, but with no significant association with PU, just like the present study.

In the assessment of comorbidities, no difference was found between those with or without PU. However, some studies have found that individuals with cardiovascular problems presented $\mathrm{PU}$ in a greater proportion than the one found in this study. In institutionalized elderly, this proportion was $47.5 \%^{(19)}$ and in patients at a hospital in São Paulo it was $43.6 \%{ }^{(27)}$, however, without significant association for PU.

No statistical difference in the proportion of underweight was found among the groups with and without PU. Patients with poor nutritional status have low albumin levels and increased risk for $\mathrm{PU}^{(22)}$. In the context of PC, reduced nutritional intake was mentioned as an associated factor in the development of PU in cancer patients ${ }^{(12)}$. It is known that patients with advanced cancer develop loss of appetite in 65 to $85 \%$ of cases and in the last days of life, 
anorexia is considered normal; nutritionally poor people have diminished skin elasticity and anemia leads to decreased tissue oxygenation ${ }^{(11,24)}$.

Almost half of the individuals with PU has had it previously ( $p=0.015)$. In the last stage of the healing process, there is the formation of granulation tissue and reepithelialization later, in which there is reorganization of collagen fibers, requiring months until its strengthening occurs. During this phase, the region remains sensitive and thinner than normal and only at the end of this process the skin gains greater strength ${ }^{(19)}$. Studies on PU do not present information on the previous occurrence of this lesion as a determining factor in the development of new wounds. However, it is known that after reepithelialization, the skin is more susceptible to further injury at the same sites ${ }^{(24)}$. Thus, people who have had PU previously must have this information valued as an additional risk factor that should be analyzed in order that the appropriate planning, implementation and evaluation of care is tailored to each client.

Most individuals with PU or their caregivers reported not having received guidance on preventing injuries. Recommendations about precautions to be taken at home to prevent PU should be part of structured programs of health education for people in PC and their families. It should include basic information about the pathophysiology and risk factors of PU, options of preventative treatment, instructions on how to minimize the risk and the development of individual care programs ${ }^{(24)}$.

The use of preventive measures was not systematically recorded in the study scenario, so it was not possible to verify whether any action in that sense had been developed. Still, it is possible that guidance has been provided, but not significantly, which may have contributed to the lack of assimilation of these measures by families and caregivers.

\section{Characterization of pressure ulcers in people with cancer in home palliative care}

Most patients showed one PU, like other studies in different population groups, in which most patients also showed a single PU, regardless of the care setting ${ }^{(15,25)}$.

Regarding the environment in which the PU emerged, the data are intriguing, because studies with other populations indicate that most of the PU arise in hospital setting, as evidenced by a study carried out at a hospital in Fortaleza, in which $96.3 \%$ of the PU arose during the period of hospitalization $^{(25)}$. In the present study, most patients were admitted to the palliative care service with PU. Patients with advanced diseases are predisposed to lesions, and in this context not all PU is preventable. However, its evolution or aggravation is worrying and may occur by the negligence of the healthcare team or caregiver ${ }^{(17)}$. Thus, it is important to evaluate the incidence of injuries globally.

The higher prevalence of lesions in the sacral region follows the pattern of the studied literature. The region is considered as the most affected in both PC (22\% to $78.4 \%$ of cases) and in other types of patients, with frequencies of $82.7 \%$ in inpatients and $71.5 \%$ in institutionalized elderly ${ }^{(6,15,19)}$.

The third stage was the most frequent, diverging from two other studies in patients in PC, in which ulcers were in stage 2 in the ratio of $29 \%{ }^{(17)}$ and $60 \%{ }^{(6)}$. In other population groups, the percentages were diverse, as follows: $38.5 \%$ of PU in stage 2 in patients admitted to a hospital in São Pau$10^{(27)}, 36.6 \%$ in stage 3 in a Spanish study in primary health care $^{(26)}$ and $72.7 \%$ in stage 4 in individuals with spinal cord injury ${ }^{(21)}$. Only in one study with patients in PC the PU were not classified and the frequency was $9.8 \%{ }^{(17)}$. No study brought the classification 'suspected deep tissue injury'.

Many patients are referred late for the PC home service, some already with PU. Besides the fact that the service overload may hinder the monitoring of patients who require periodic visits, other important factors are the training and the availability of material resources for the application of the dressings by caregivers, which does not always occur.

The way caregivers perform the care and apply the received guidance or not, may influence the conditions of the PU in each patient. However, even with meticulous care, the lesion may deteriorate if the systemic conditions of the patient shows unfavorable outcomes.

The mean score of the PUSH scale was approximately nine and no studies were found with patients in palliative care that assessed the PU using the PUSH. It is believed that the use of measurement instruments is important to allow standardization of the evaluation strategy, the comparison of results from different groups, at different times, and the possibility of identifying potential instrument errors.

A study evaluating the traditional method of documentation and evaluation of PU using the PUSH found that $13 \%$ of the traditional documentation judged that the PU had decrease in size. However, $52 \%$ of the observations by PUSH scores showed a decrease of the total score, demonstrating that traditional documentation shows no correlation with the assessment by $\mathrm{PUSH}^{(28)}$.

Individuals in PC constitute a complex clientele that demands a service with different features in its organizational structure. The studied service faces difficulties due to the high number of patients and lack of physical infrastructure and human resources for outpatient care, which increases the interval time between the assessments of nurses, and this may hinder early detection of lesions.

A limitation of the study was the small number of patients with PU. It would have been important to include a larger number of participants to be able to perform more robust statistical tests. However, this is the only public service in Goiás with the philosophy of PC and this study represents an effective contribution when revealing the prevalence and characteristics of the PU. Although no significant associations were observed, the research brought knowledge about risk
Pressure ulcers in palliative home care patients: prevalence and characteristics Queiroz ACCM, Mota DDCF, Bachion MM Ferreira ACM 
factors for PU such as age, nutritional status, urinary incontinence, smoking and high dependency to self-care.

The results of this study will enable the PC teams to review their practices. The guidance strategies for caregivers, both for prevention and for the treatment of PU may become more effective. To this end, a practice closer to patients and their families is needed, allowing not only more frequent home visits, but also alternative interventions through telephone monitoring or institutional folders with basic guidelines on PU, among other possibilities. It is necessary to advance the systematization of nursing care in order to perform the primary and secondary prevention of PU, which includes early diagnosis of these lesions.

\section{CONCLUSION}

This study showed the PU prevalence of $18.8 \%$ in cancer patients receiving PC at home. Compared to other studies, this prevalence is intermediate. However, as this is an event that can be prevented and that has physical, psychological, social and economic negative impact, its occurrence is always worrying and strategies need to be employed to change this scenario.

Regarding the sociodemographic and clinical characteristics, no differences between the profile of patients

\section{REFERENCES}

1. Maciel MGS. Definições e princípios. In: Oliveira RA, coordenador. Cuidado paliativo. São Paulo: CREMESP; 2008. p. 1533.

2. World Health Organization (WHO). National Cancer Control Programmes: policies and managerial guidelines. 2 nd ed. Geneva: WHO; 2002.

3. Silva MJP, Araújo MT, Firmino F. Enfermagem. In: Oliveira RA, coordenador. Cuidado paliativo. São Paulo: CREMESP; 2008. p. 61-3.

4. World Health Organization (WHO). Fight Against Cancer: strategies that prevent, cure and care. Geneva: WHO; 2007.

5. Brasil. Ministério da Saúde; Instituto Nacional do Câncer. Tratamento e controle de feridas tumorais e úlceras por pressão no câncer avançado: série cuidados paliativos. Rio de Janeiro: INCA; 2009.

6. Galvin J. An audit of pressure ulcer incidence in a palliative care setting. Int J Palliat Nurs. 2002;8(5):214-21.

7. Brink P, Smith TF, Linkewich B. Factors associated with pressure ulcers in palliative home care. J Palliat Med. 2006;9(6):136975. with and without PU were observed. Probably because of the size of the studied population and the specificities of participants, who can have the same classic risk factors for PU because they all have cancer and are in PC.

The only exception concerns the history of previous $\mathrm{PU}$, because this factor was significantly associated with the emergence of PU. This result should be valued, since the individual who has had a previous injury requires attention from nurses and the multidisciplinary team in order to prevent and early diagnose any recurrence.

The higher prevalence of lesions in the sacral region follows the pattern of the studied literature. The stage 3 was the most frequent, unlike the majority of other studies with patients in palliative care. The mean score of the PUSH scale was approximately nine.

The characteristics of the PU observed in this study should be a reason of concern to PC teams. It should be taken into consideration that not only the frequency of PU was high but there was more than one lesion, many of which at advanced stage, and that appeared in the household. PC domiciliary teams should detect PU early and invest in effective prevention care and treatment to provide more comfort and quality of life for this population.

8. Hendrichova I, Castelli M, Mastroianni C, Piredda M, Mirabella $F$, Surdo L, et al. Pressure ulcers in cancer palliative care patients. Palliat Med. 2010;24(7):669-73.

9. Santos VLCG, Azevedo MAJ, Silva TS, Carvalho VM, Carvalho VF. Adaptação transcultural do Pressure Ulcer Scale for Healing (PUSH) para a língua portuguesa. Rev Latino Am Enferm. 2005;13(3):305-13.

10. Thomas DR, Rodeheaver GT, Bartolucci AA, Franz RA, Sussman C, Ferrell BA, et al. Pressure ulcer scale for healing: derivation and validation of the PUSH tool. The PUSH Task Force. Adv Wound Care. 1997;10(5):96-101.

11. Brasil. Ministério da Saúde; Secretaria de Atenção à Saúde, Departamento de Atenção Básica. Envelhecimento e saúde da pessoa idosa. Brasília; 2007. (Cadernos de Atenção Básica, 19).

12. Reifsnyder J, Magee HS, Development of pressure ulcers in patients receiving home hospice care. Wounds. 2005;17(4):74-9.

13. Cai MSS, Mukamel DB, Temkin-Greener H. Pressure ulcer prevalence among black and white nursing home residents in New York State: evidence of racial disparity? Med Care. 2010;48(3):233-39. 
14. Capon A, Pavoni N, Mastromattei A, Di Lallo D. Pressure ulcer risk in long-term units: prevalence and associated factors. J Adv Nurs. 2007;58(3):263-72.

15. Gomes FSL, Bastos MAR, Matozinhos FP, Temponi HR, Velásquez-Meléndez G. Factors associated to pressure ulcers in patients at Adult Intensive Care Units. Rev Esc Enferm USP [Internet]. 2010 [cited 2013 May 25];44(4):1070-6. Available from: http://www.scielo.br/pdf/reeusp/v44n4/en_31.pdf

16. Baumgarten $M$, Margolis $D$, Van Doorn $C$, Gruber-Baldini AL, Hebel JR, Zimmerman S, et al. Black/White differences in pressure ulcer incidence in nursing home residents. J Am Geriatr Soc. 2004;52(8):1293-8.

17. Maida V, Ennis M, Corban J. Wound outcomes in patients with advanced illness. Int Wound J. 2012;9(6):683-92.

18. Malaquias SG, Bachion MM, Nakatani AYK. Risco de integridade da pele prejudicada em idosos hospitalizados. Cogitare Enferm. 2008;13(3):428-36.

19. Chacon JMF, Blanes L, Hochman B, Ferreira LM. Prevalence of pressure ulcers among the elderly living in long-stay institutions in São Paulo. Med J. 2009;127(4):211-5.

20. Tsutakawa S, Kobayashi D, Kusama M, Moriya T, Nakahata N. Nicotine enhances skin necrosis and expression of inflammatory mediators in a rat pressure ulcer model. Br J Dermatol. 2009;161(5):1020-7.

21. Rabadi MH, Vincent AS. Do vascular risk factors contribute to the prevalence of pressure ulcer in veterans with spinal cord injury? J Espinal Cord Med. 2011;34 (1):46-51.
22. Bergquist-Beringer S, Gajewski BJ. Outcome and assessment information set data that predict pressure ulcer development in older adult home health patients. Adv Skin Wound Care. 2011;24(9):404-14.

23. Paquay L, Verstraete $S$, Wouters R, Buntinx F, Vanderwee $K$, Defloor $T$, et al. Implementation of a guideline for pressure ulcer prevention in home care: pretest-post-test study. J Clin Nurs. 2010;19(13-14):1803-11.

24. Dealey C. Cuidando de feridas. 2a ed. São Paulo: Atheneu; 2001.

25. Sanders LSC, Pinto FJM. Ocorrência de úlcera por pressão em pacientes internados em um hospital público de Fortaleza, CE. Rev Min Enferm. 2012;16(2):166-70.

26. Soldevilla Agreda JJ, Torra i Bou JE, Verdú Soriano J, Martinez Cuervo F, López Casanova P, Rueda López J, et al. 2o Estudio nacional de prevalencia de úlceras por presión en España, 2005. Epidemiología y variables definitorias de las lesiones y pacientes. Gerokomos. 2006;17(3):154-72.

27. Blanes L, Duarte IS, Calil JA, Ferreira LM. Avaliação clínica e epidemiológica das úlceras por pressão em pacientes internados no Hospital São Paulo. Rev Assoc Med Bras. 2004;50(2):182-7.

28. George-Saintilus E, Tommasulo B, Cal CE, Hussain R, Mathew $\mathrm{N}$, Dlugacz $\mathrm{Y}$, et al. Pressure ulcer PUSH Score and traditional nursing assessment in nursing home residents: do they correlate? J Am Med Dir Assoc. 2009(10):141-4.
Correspondence address to: Ana Carolina de Castro Mendonça Queiroz Rua Princesa Isabel, Qd. 31A, It. 13/23, Apt. 202

Bloco F, Jardim Maria Inês

CEP 74917-150 - Goiânia, GO, Brazil 